\title{
重症患者における発熱と解熱処置に関するsystematic review
}

\author{
江木 盛時*1＼cjkstart西村 匡司*2＼cjkstart森田＼cjkstart潔*1
}

\begin{abstract}
要約：【背景】重症患者の発熱は頻繁に生じ，外表クーリングや薬物による解熱処置が日々行 われている。しかし，発熱を解熱すべきか否かに関する治療指針は存在しない。【方法】発熱 と解熱処置が患者予後に与える影響に関して systematic reviewを行った。【結果】発熱あるい は解熱処置が患者予後に与える影響を検討した研究は, 27 文献存在した。これらの文献から, 以下のような見解を得た。(1)発熱の発生は, 重症患者の死亡率増加に関与する。(2)感染症合 併患者では，発熱が死亡率低下に関与する可能性がある。(3)発熱に関する観察研究で解熱処 置の情報を含めて解析したものはない。(4)積極的に解熱処置を行うことで，患者予後が悪化 する可能性がある。【結語】重症患者の発熱を解熱すべきであることを示す根拠はそしく，一 概に解熱処置を行うことは推奨されない。この分野の知見を深めるために，十分な powerの 大規模多施設前向き観察研究を実施する必要がある。
\end{abstract}

Key words: (1) fever, (2) antipyretic, (3) mortality, (4) critically ill, (5) systematic review

\section{I. 背 景}

発熱は, 集中治療を要する重症患者に頻繁に生じる

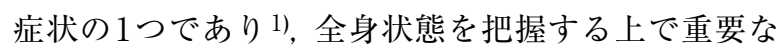
指標となる。実際, 発熱を契機に新たな診察, 検査, 治療が開始されることは稀ではない2)。また発熱は, 手術 $31 \sim 6$, 輸血 ${ }^{7}$, 薬剂投与 87,9 , 急性拒絶 ${ }^{10)}$ など感染 症以外の要因でも生じる。

発熱は, 患者不快感, 呼吸需要および心筋酸素需要 の増大 ${ }^{11)}$, 中枢神経障害12),13)などを生じるため,これ らの改善を期待して, 外表冷却や解熱薬による解熱処 置が行われる14)

しかし感染症による体温上昇は, 抗体産生の増加, $\mathrm{T}$ 細胞の活性化，サイトカインの合成，好中球抒よび マクロファージの活性化を惹起させる自己防衛反応で あり 15) 17), 解熱処置によりこれらの防衛反応が抑制 される可能性もある。また解熱薬には, 胃腸障害, 肝 障害, 腎障害などの副作用もある18)。

中枢神経障害を有する患者においては, 発熱が生命

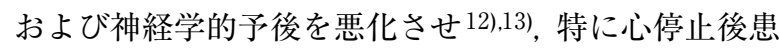

者では軽度低体温が患者予後を改善させる 19 ),20)。 しかし, 中枢神経障害を有さない重症患者において, どのように発熱をコントロールし, 解熱処置を行うべ きかについては, 明確な指針が存在しない2,21,22)。

この発熱と解熱処置が患者予後 (特に患者死亡率) に与える影響に関する知見を整理することを目的に, 我々は, 重症患者に打ける発熱と解熱処置に関する systematic reviewを行った。

\section{II. 研究方法}

我々は, 発熱と解熱処置が重症患者の死亡率に及ぼ す影響に関する文献を網羅的に検索した。文献検索に 際しては, 事前に, 論文の検索方法, 選択基準, 選択方 法および検討する命題を決定した。

\section{1) 論文の検索方法}

1978年から 2008年までの31年間にMEDLINEと PubMedに揭載された論文について, “hyperthermia", "fever", "temperature", "intensive care", “critically ill”, “ICU”, “death”, “mortality”のキー ワードを用いて検索を行った。電子的検索で抽出でき 


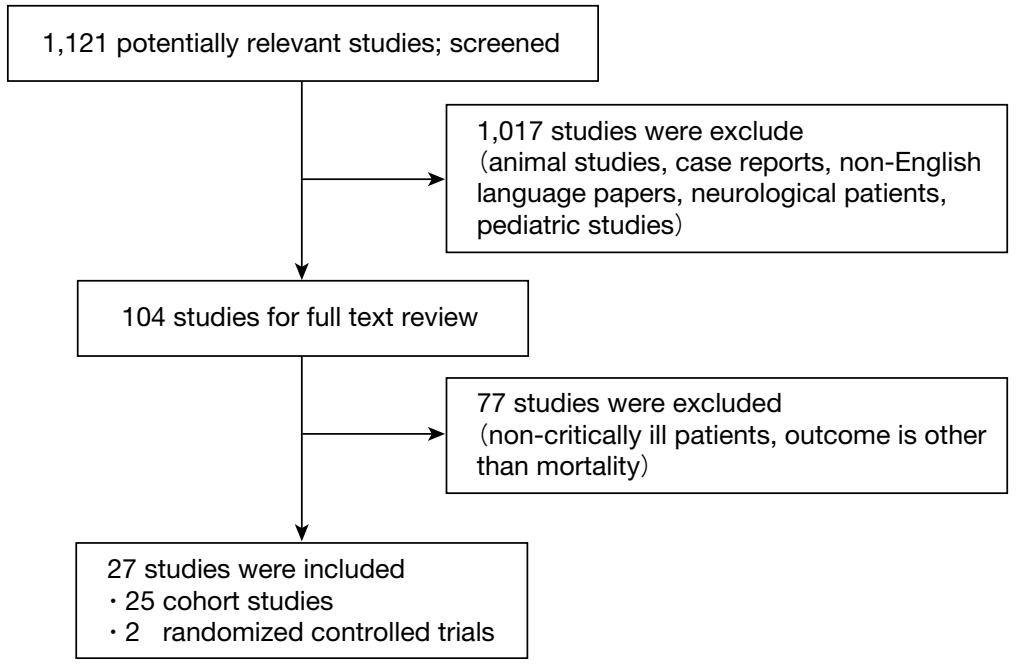

Fig. 1 Study selection for inclusion systematic review for fever and antipyretic therapy in critically ill adults

なかった論文数を可能な限り少なくするために, 検索 された論文の参考文献も対象とした。

\section{2）論文の選択基準}

電子的検索で抽出された論文から, 20 歳以上の中枢 神経障害を持たない重症患者を対象とした研究で, 発 熱あるいは解熱処置と死亡率との関連を検討した研究 を対象として選択した。症例報告, 英語以外の論文, 動物実験, in vitroの研究，および熱中症に関する研究 は除外した。

\section{3）論文の選択方法}

2名の著者がそれぞれ，検索された全ての論文の タイトル拉よび抄録の確認を行った。対象論文の可能 性があると判断した全ての論文のfull-textを確認し, systematic reviewに使用する論文を選択した。

\section{4) Systematic reviewにより検討する命題}

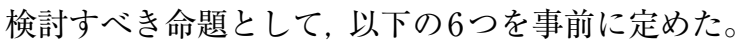

(1)重症患者に打ける発熱の定義は?

(2)研究期間中, 体温測定はどのように行われている か?

(3)発熱の発生率は?

(4)発熱は患者予後にどのように関与するか？

(5)解熱処置が患者予後にどのように関与するか？

(6)解熱処置を行う基準となる体温は存在するか？

\section{III. 結 果}

電子的検索により1,121の文献を抽出した。この うち, タイトルと抄録の確認により，104研究を対象 論文の可能性があると判断した。この104研究の full-textを確認し, 27 研究 1),14),23) 47) reviewの対象として選択した (Fig. 1)。27研究中, ランダム化比較試験が 2 研究 14),29), 前向き観察研究が 18研究 23),24),26),28),30) 331,35) 42),45),47), 後万向き観察研 究が7研究 1),25),27),34),43),44),46)であった。対象 27 研究中, 24 研究は1施設研究 14),23) 25),27) 40),42) 47), 3研究は 多施設研究であった 11,26$), 411 。$

\section{1）発熱の定義は?}

対象の 27 研究の全てで, 発熱の定義が提示されて いた。発熱の定義は一律ではなく, 最低 $37.5^{\circ} \mathrm{C}$ から 最高 $39.0^{\circ} \mathrm{C}$ までばらついており，その中でも多かっ たのが $38.0^{\circ} \mathrm{C}$ が9研究 231,30$\left.\left.) ~ 331,35,40\right), 42,47\right), 38.3^{\circ} \mathrm{C}$ が 7 研究 1),26),28),36),37),41),45), $38.5^{\circ} \mathrm{C}$ が5研究 14),25),29, 44),46) で, 平均は $38.2 \pm 0.4^{\circ} \mathrm{C}$ であった (Fig. 2)。38. $33^{\circ} \mathrm{C}$ を選択し た研究は, 華氏 101 度以上 $\left(>38.3^{\circ} \mathrm{C}\right)$ を発熱と定義し ていた。

2）研究期間中の体温測定はどのように行われてい るか?

対象の 27 研究の中で, 体温測定部位について記載 があった研究は7研究のみであり 1),34),36),38),391,41),44)，そ の他の 20 研究では明確な測定部位の記載はなかった。 測定部位の記載があった 7 研究においても統一された 測定法はなく, 4研究で直腸温 $\left.\left.{ }^{37}, 39,42\right), 45\right)$ を, 3研究で 鼓膜温 ${ }^{1), 34), 39)}$ を, 3 研究で血液温 1 (1),34),36), そして 1 研究 で口胿温 ${ }^{38)}$ を使用していた (7研究のうち4研究で, 測 定部位の記載が2カ所あった)。

\section{3）発熱の発生率は?}

対象の 27 研究の中で, 発熱発生率について報告し た研究は9研究あった 1),231,25),341,36),37),39),42),43)。各研究 の発熱の定義や患者背景は異なっており, 発生率は ばらついていた。最低は外傷患者を対象とした研究の 


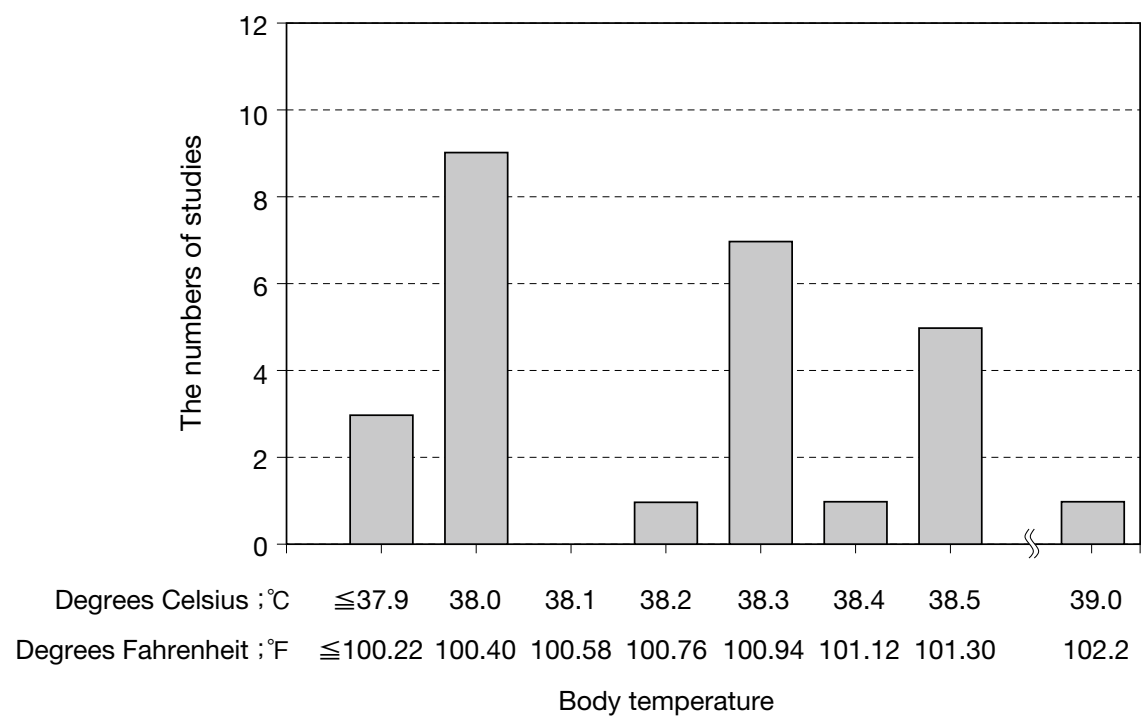

Fig. 2 Comparison of the definitions of fever in 27 articles

18\% (発熱の定義； $38.5^{\circ} \mathrm{C}$ ) 25), 最高はARDSを対象と した研究の $93 \%$ (発熱の定義； $38.3^{\circ} \mathrm{C}$ ) であった ${ }^{42) 。 ~}$ 発熱の定義を $38.0^{\circ} \mathrm{C}$ 以上とした 3 研究での発熱発生率 は平均 $\left.\left.70.6 \%{ }^{23)}, 42\right), 43\right), 38.2 \sim 38.5^{\circ} \mathrm{C}$ 以上とした 6 研究 では34.2\%であった1),25),34),36),37),39)。

\section{4）発熱は患者予後によ゙のように関連するか?}

発熱群と非発熱群の患者死亡率の比較を行った研究 は6研究あった 1),34),36),37),39),43) (Table 1)。単変量解析 では, 3研究で発熱群の死亡率が有意に高く34),36),37), 2 研究で両群に有意差はなく1),39), 残りの1研究で非発 熱群の死亡率が有意に高かった43)。この6つの研究 を fixed-effect modelでメ夕解析した結果, 発熱群は非 発熱群と比較して死亡率が $30 \%$ 高かった (Table 1)。

発熱群で死亡率が高かった 4 研究の平均発熱発生率 は $35.1 \%$, 感染症合併率は $23.5 \%$ であたのに対し, 残り 2 研究の平均発熱発生率は $69.9 \%$, 感染症合併率 は76.0\%であった。これら全ての観察研究で, 解熱処 置の情報は集積されていなかった。

なお，感染症患者と非感染症患者に分けて発熱と患 者予後との関係を解析, 比較した文献は存在しなかっ た。

5）解熱処置が患者予後にどのように関与するか? 重症患者の発熱に対する解熱処置が患者予後に与え る影響について検証した研究は2 研究あり 14),29), 共に 1 施設ランダム化比較試験であった。発熱の定義はい ずれも $38.5^{\circ} \mathrm{C}$ 以上であった (Table 2 )。

Schulmanらは, 外傷患者 82 人を, $>38.5^{\circ} \mathrm{C}$ の発熱 でアセトアミノフェン投与し $>39.5^{\circ} \mathrm{C}$ でクーリングを 追加する群 44 人 (以下, 積極解熱群) と, $>40.0^{\circ} \mathrm{C}$ の発
熱でアセトアミノフェン投与とクーリングを行う群 38 人 (以下, 発熱許容群) とに無作為に分け検討を行っ た ${ }^{29)}$ 。ICU死亡率は, 積極解熱群 $15.9 \%(7 / 44)$, 発熱 許容群 $2.6 \%(1 / 38)$ と有意差はないものの, 積極解熱 群で高い傾向を認めた (odds比；7.1, $P=0.06) 。$ 死 亡率以外の検討では, 感染症発生率, 人工呼吸期間, 在院日数に有意な差を認めなかったが, 発熱許容群で 抗菌薬使用量の有意な減少を認めた $(P=0.007) 29)$ 。

一方, Gozzoliらは, 術後患者 38 人を, $38.5^{\circ} \mathrm{C}$ 以上で クーリングする群 18 人 (以下, クーリング群) と, $38.5^{\circ} \mathrm{C}$ 以上でも解熱処置を行わない群 20 人 (以下, 対 照群) とに無作為に分け検討を行った。ICU死亡率は クーリング群15\%(3/20), 対照群 $11 \%(2 / 18)$ で, 有 意差を認めなかった $(P=0.99)$ 。死亡率以外の検討で も, 抗菌薬使用量, 感染症発生率, 人工呼吸期間, 在院 日数に有意差を認めなかった ${ }^{14)}$ 。

この 2 つ研究を fixed-effect modelで解析すると, 解熱処置を行うことで, 有意ではないが患者死亡率が $60 \%$ 増加することが示唆された。

なお, どの解熱処置が患者予後改善に有利に働くか を示唆する文献は存在しなかった。

6）解熱処置を行う基準となる体温は存在するか?

前述のごとく, 解熱処置の patients centered outcome に対する有効性を報告した論文は存在せず, 解熱処置を 行う基準となる体温を報告した論文も存在しなかった。

\section{IV. 考 察}

発熱は, 外因性の刺激に対して産生された内因性 
日集中医誌 J Jpn Soc Intensive Care Med Vol. 18 No. 1
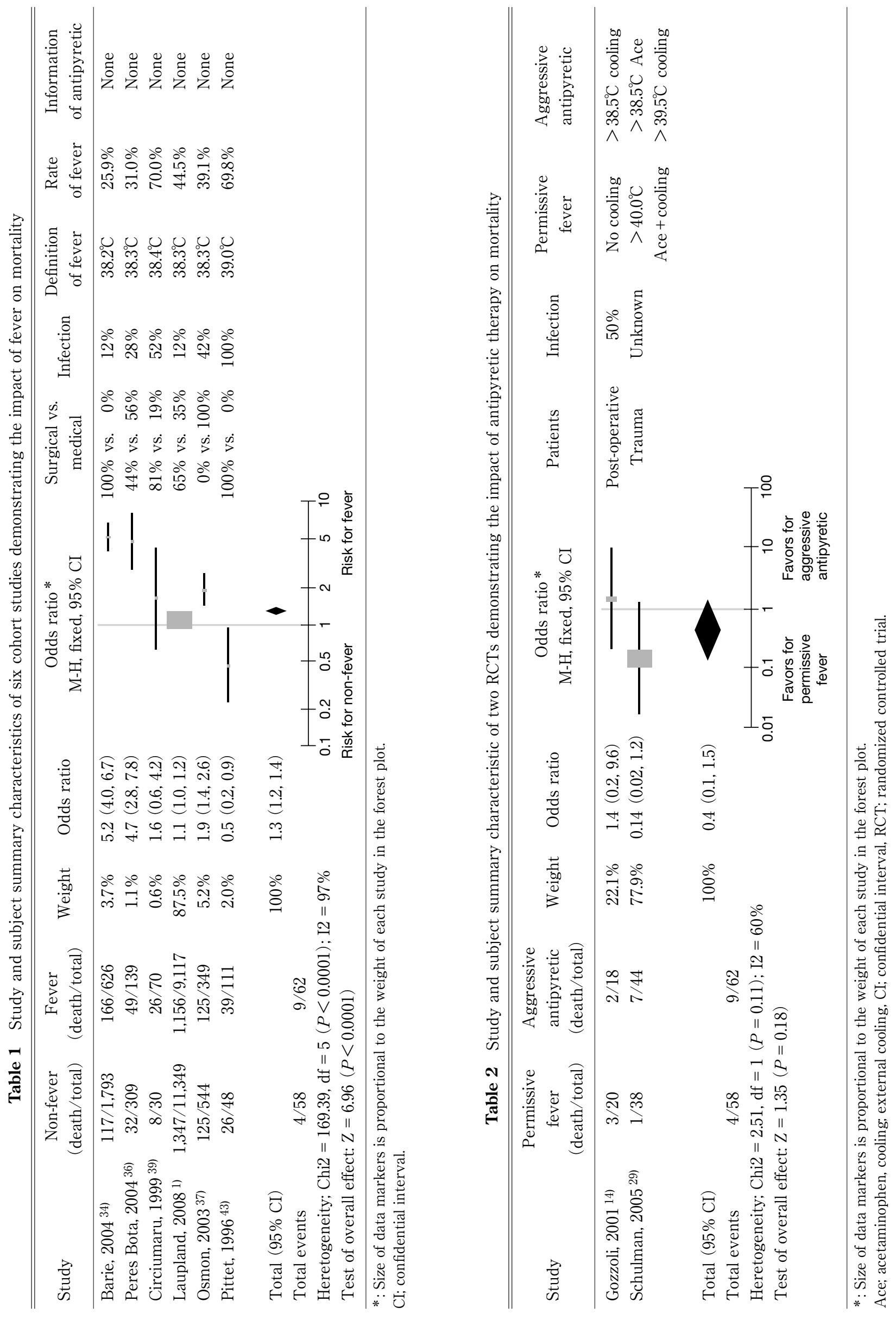
IL-1 や TNF- $a$ などが中枢神経の終板血管器官に作用 し, プロスタグランジン E20合成, アラキドン酸カス ケードを介してシクロオキシゲナーゼ 2 を産生するこ とによって生じる ${ }^{48)}$ 。重症患者では, 手術, 外傷, 感 染などを起因として, 発熱が頻繁に生じる1)。しかし, 近年報告された発熱した重症患者に関するガイドライ ンにおいても, 発熱をどのようにコントロールするべ きかについて明確な提言はされていない2)。

今回我々は, 発熱あるいは解熱処置と患者予後との 関係に関する研究論文を対象として, 網羅的検索を行 い, 27 文献を選択した。この 27 文献から得られた情 報を基に, 事前に用意した命題に対して以下のような 見解を導きだした。

\section{1) 見解1 (発熱の定義)}

・発熱の定義は統一されていない。

American College of Critical Care Medicine (ACCM) と Infectious Diseases Society of America (IDSA) から報告された重症患者の発熱に関するガイ ドラインでは, $38.3^{\circ} \mathrm{C}$ 以上を発熱と定義している ${ }^{2)}$ 。 しかし, 今回得られた文献では, $38.0^{\circ} \mathrm{C}$ や $38.5^{\circ} \mathrm{C}$ な゙ の体温も発熱の定義として頻用されていた。

統一された発熱の定義がないことは, 各研究間の結 果が大きくばらつき, 解熱処置に関する比較介入試験 がほとんど行われていない原因となっていると考えら れる。今後, 大規模な観察研究により発熱の定義が提 言されれば, 解熱処置の是非を検討する比較介入試験 を実施するための素地となりうる。

2) 見解 2 (測定部位)

・測定部位を報告した研究は少なく, 報告された測 定部位も一律でない。

体温は測定部位で正確さが異なるため, 臨床では可 能な限り信頼度の高い測定部位を使用し, 測定時には その部位を記録することが重要である。 ACCM と IDSAのガイドラインでは, 血液温度, 膀胱温度, 食道 温度, 直腸温度が中核温をより正確に反映するとして, その使用を推奨している。一方, 腋下温度, 未梢血管 温度 (末梢動脈カテーテルで測定される血液温度) は 信頼性が低く, ICUでの使用は推奨されていない2)。

今回対象となった文献のうち, 測定部位の記載があ

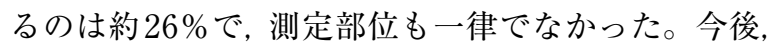
重症患者の発熱と解熱処置に関する研究を行う場合, 測定部位を統一することが望ましく，それが困難であ る場合でも, 測定部位の記録は不可欠であると考えら れる。

3) 見解3 (発熱発生率)

・発熱発生率は, 発熱の定義・患者背景により大き
く影響を受け，一定の見解を得られない。

\section{4) 見解4 (発熱と患者予後との関係)}

・発熱は, 患者死亡率の $30 \%$ 増加に関与する。

・感染症合併患者では, 発熱が患者死亡率の低下に 関与する可能性が示唆された。

・感染症患者と非感染症患者を分けて, 発熱と患者 予後との関係を解析, 比較した研究は存在しな w。

・全ての観察研究で, 発熱と患者死亡率との関連性 の解析に解熱処置の情報が含められていない。

(1) 発熱と患者死亡率

メ夕解析の結果, 発熱が患者死亡率の $30 \%$ 増加と関 連することが示唆された。また, 重症度などの患者情 報を調整した多変量解析を行った上で, 発熱と患者死

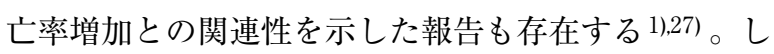
かし, これらの結果は全て, 発熱と患者死亡率との関 係を調查した観察研究から得られたものであるため, これらの情報から, 発熱と患者死亡率増加との因果関 係を結論付けることはできない。

(2) 発熱と死亡率の関係に対する感染症の関わり

発熱患者で死亡率が高いと報告した 4 文献の感染症 合併率が $23.5 \%$ あったたのに対して, 同等あるいは低 いと報告した 2 文献の感染症合併率は 3 倍以上の $76 \%$ であった $(P<0.01)$ 。の結果は, 発熱と患者予後の 関係が, 感染症患者と非感染症患者で異なっている可 能性を示唆している。

しかし, これらの結果は全て, 発熱と患者死亡率と の関係を調査した観察研究から得られたものであるた め, これらの情報から, 発熱と患者死亡率増加との因 果関係を結論付けることはできない。感染症患者と非 感染症患者で解熱治療法の有効性が異なるか否かを検 討するには, 感染症の有無でサブ解析できる程, 集積 患者数の多いランダム化比較試験が必要となる。

\section{5) 見解5(解熱処置亡患者予後の関係)}

- 解熱処置の患者予後に対する有効性・有害性を 検討した観察研究は存在しない。

・解熱処置の患者予後に対する有効性・有害性を 検討したランダム化比較試験は, 小規模研究が 2 つ存在し, $38.5^{\circ} \mathrm{C}$ 以上の発熱を積極的に解熱する ことで, 患者死亡率が増加する可能性が示唆され た。

重症患者に対する解熱処置が患者予後に与える影響

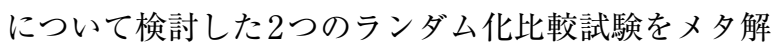
析した結果は, 重症患者に対する安易な解熱処置に対 し注意を呼びかけるものであった。

しかし, この $2 つ の$ 研究はいずれも小規模 1 施設研 
究であり,この結果のみで解熱処置の有益性・有害性 について結論を出すことはできない。十分な情報を 持った大規模多施設前向き観察研究を行い, その結果 を再検討する必要がある。

\section{6）見解 6 (解熱処置の施行基準)}

・解熱処置を行う基準を示唆する文献は存在しな い。

\section{V. まとめ}

重症患者の発熱に解熱処置を行うべきか否か, いつ 解熱処置を行うべきか, どの解熱処置を選択すべきか, どの患者群に解熱処置を行うべきか，の疑問に明確に 答えるための根拠はそしい。しかし，重症患者の発熱 を一律に解熱させることは推奨されない。

小規模ランダム化比較試験で, 解熱処置が患者に不 利益を与える可能性が示唆されているため, 重症患者 の発熱に対する解熱処置の効果を検討する大規模ラン ダム化比較試験を行うことは倫理的に困難である。こ の分野の知見をより深めるためには, 発熱の定義, 体 温測定部位, 患者背景, 感染症の有無, 解熱処置の情 報を同時に集積し，十分な powerでsubgroup解析が 可能な大規模多施設前向き観察研究を実施する必要が ある。

本論文の要旨は, 第37回日本集中治療医学会学術集会 (広 島, 2010年)で発表した。

\section{文 献}

1) Laupland KB, Shahpori R, Kirkpatrick AW, et al. Occurrence and outcome of fever in critically ill adults. Crit Care Med 2008;36:1531-5.

2) O'Grady NP, Barie PS, Bartlett JG, et al. Guidelines for evaluation of new fever in critically ill adult patients: 2008 update from the American College of Critical Care Medicine and the Infectious Diseases Society of America. Crit Care Med 2008;36:1330-49.

3) Freischlag J, Busuttil RW. The value of postoperative fever evaluation. Surgery 1983;94:358-63.

4) Galicier C, Richet H. A prospective study of postoperative fever in a general surgery department. Infect Control 1985;6:487-90.

5) Badillo AT, Sarani B, Evans SR. Optimizing the use of blood cultures in the febrile postoperative patient. J Am Coll Surg 2002;194:477-87; quiz 554-6.

6) Garibaldi RA, Brodine S, Matsumiya S, et al. Evidence for the non-infectious etiology of early postoperative fever. Infect Control 1985;6:273-7.

7) Kennedy LD, Case LD, Hurd DD, et al. A prospective, randomized, double-blind controlled trial of acetaminophen and diphenhydramine pretransfusion medication versus placebo for the prevention of transfusion reactions. Transfusion 2008;48:2285-91.

8) Roush MK, Nelson KM. Understanding drug-induced febrile reactions. Am Pharm 1993;NS33:39-42.

9) Tabor PA. Drug-induced fever. Drug Intell Clin Pharm 1986;20:413-20.

10) Hawksworth JS, Leeser D, Jindal RM, et al. New directions for induction immunosuppression strategy in solid organ transplantation. Am J Surg 2009;197:515-24.

11) Laupland KB. Fever in the critically ill medical patient. Crit Care Med 2009;37:S273-8.

12) Azzimondi G, Bassein L, Nonino F, et al. Fever in acute stroke worsens prognosis. A prospective study. Stroke 1995;26:2040-3.

13) Rossi S, Zanier ER, Mauri I, et al. Brain temperature, body core temperature, and intracranial pressure in acute cerebral damage. J Neurol Neurosurg Psychiatry 2001;71:448-54.

14) Gozzoli V, Schottker P, Suter PM, et al. Is it worth treating fever in intensive care unit patients? Preliminary results from a randomized trial of the effect of external cooling. Arch Intern Med 2001;161:121-3.

15) Ryan AJ, Flanagan SW, Moseley PL, et al. Acute heat stress protects rats against endotoxin shock. J Appl Physiol 1992;73:1517-22.

16) Villar J, Ribeiro SP, Mullen JB, et al. Induction of the heat shock response reduces mortality rate and organ damage in a sepsis-induced acute lung injury model. Crit Care Med 1994;22:914-21.

17) Kluger MJ, Kozak W, Conn CA, et al. The adaptive value of fever. Infect Dis Clin North Am 1996;10:1-20.

18) Plaisance KI. Toxicities of drugs used in the management of fever. Clin Infect Dis 2000;31 Suppl 5:S219-23.

19) Hypothermia after Cardiac Arrest Study Group. Mild therapeutic hypothermia to improve the neurologic outcome after cardiac arrest. N Engl J Med 2002;346: 549-56.

20) Bernard SA, Gray TW, Buist MD, et al. Treatment of comatose survivors of out-of-hospital cardiac arrest with induced hypothermia. N Engl J Med 2002;346:557-63.

21) Dellinger RP, Levy MM, Carlet JM, et al. Surviving Sepsis Campaign: international guidelines for management of severe sepsis and septic shock: 2008 . Intensive Care Med 2008;34:17-60.

22) Dellinger RP, Levy MM, Carlet JM, et al. Surviving Sepsis Campaign: international guidelines for management of severe sepsis and septic shock: 2008. Crit Care Med 2008;36:296-327.

23) Cheval C, Timsit JF, Garrouste-Orgeas M, et al. Procalcitonin $(\mathrm{PCT})$ is useful in predicting the bacterial origin of an acute circulatory failure in critically ill patients. Intensive Care Med 2000;26 Suppl 2:S153-8.

24) Martini A, Gottin L, Melot C, et al. A prospective evaluation of the Infection Probability Score (IPS) in the intensive care unit. J Infect 2008;56:313-8.

25) Golob JF Jr, Claridge JA, Sando MJ, et al. Fever and leukocytosis in critically ill trauma patients: it's not the urine. Surg Infect (Larchmt) 2008;9:49-56.

26) Combes A, Luyt CE, Fagon JY, et al. Early predictors for infection recurrence and death in patients with ventilatorassociated pneumonia. Crit Care Med 2007;35:146-54.

27) de Rooij SE, Govers A, Korevaar JC, et al. Short-term and long-term mortality in very elderly patients admitted to an intensive care unit. Intensive Care Med 2006;32: 1039-44. 
28) Fraunberger P, Wang Y, Holler E, et al. Prognostic value of interleukin 6, procalcitonin, and C-reactive protein levels in intensive care unit patients during first increase of fever. Shock 2006;26:10-2.

29) Schulman CI, Namias N, Doherty J, et al. The effect of antipyretic therapy upon outcomes in critically ill patients: a randomized, prospective study. Surg Infect (Larchmt) 2005;6:369-75.

30) Jaber S, Chanques G, Altairac C, et al. A prospective study of agitation in a medical-surgical ICU: incidence, risk factors, and outcomes. Chest 2005;128:2749-57.

31) Vidaur L, Gualis B, Rodriguez A, et al. Clinical resolution in patients with suspicion of ventilator-associated pneumonia: a cohort study comparing patients with and without acute respiratory distress syndrome. Crit Care Med 2005;33:1248-53.

32) Povoa P, Coelho L, Almeida E, et al. C-reactive protein as a marker of ventilator-associated pneumonia resolution: a pilot study. Eur Respir J 2005;25:804-12.

33) Memis D, Karamanlioglu B, Turan A, et al. Effects of lornoxicam on the physiology of severe sepsis. Crit Care 2004;8:R474-82

34) Barie PS, Hydo LJ, Eachempati SR. Causes and consequences of fever complicating critical surgical illness. Surg Infect (Larchmt) 2004;5:145-59

35) Pawar M, Mehta Y, Kapoor P, et al. Central venous catheter-related blood stream infections: incidence, risk factors, outcome, and associated pathogens. J Cardiothorac Vasc Anesth 2004;18:304-8.

36) Peres Bota D, Lopes Ferreira F, Mélot C, et al. Body temperature alterations in the critically ill. Intensive Care Med 2004;30:811-6.

37) Osmon S, Warren D, Seiler SM, et al. The influence of infection on hospital mortality for patients requiring $>48 \mathrm{~h}$ of intensive care. Chest 2003;124:1021-9.

38) Singh N, Chang FY, Gayowski T, et al. Fever in liver transplant recipients in the intensive care unit. Clin Transplant 1999;13:504-11.
39) Circiumaru B, Baldock G, Cohen J. A prospective study of fever in the intensive care unit. Intensive Care Med 1999;25:668-73.

40) Talmor M, Hydo L, Barie PS. Relationship of systemic inflammatory response syndrome to organ dysfunction, length of stay, and mortality in critical surgical illness: effect of intensive care unit resuscitation. Arch Surg 1999;134:81-7.

41) Sands KE, Bates DW, Lanken PN, et al. Epidemiology of sepsis syndrome in 8 academic medical centers. JAMA 1997;278:234-40.

42) Headley AS, Tolley E, Meduri GU. Infections and the inflammatory response in acute respiratory distress syndrome. Chest 1997;111:1306-21.

43) Pittet D, Thievent B, Wenzel RP, et al. Bedside prediction of mortality from bacteremic sepsis. A dynamic analysis of ICU patients. Am J Respir Crit Care Med 1996;153: 684-93.

44) Schwenzer KJ, Gist A, Durbin CG. Can bacteremia be predicted in surgical intensive care unit patients? Intensive Care Med 1994;20:425-30.

45) Antonelli M, Moro ML, Capelli O, et al. Risk factors for early onset pneumonia in trauma patients. Chest 1994; 105:224-8.

46) Poole GV, Muakkassa FF, Griswold JA. The role of infection in outcome of Multiple Organ Failure. Am Surg 1993;59:727-32.

47) Marshall J, Sweeney D. Microbial infection and the septic response in critical surgical illness. Sepsis, not infection, determines outcome. Arch Surg 1990;125:17-22.

48) Plaisance KI, Mackowiak PA. Antipyretic therapy: physiologic rationale, diagnostic implications, and clinical consequences. Arich Intern Med 2000;160:449-56.

49) Marik PE. Fever in the ICU. Chest 2000;117:855-69.

50) Parrillo JE, Parker MM, Natanson C, et al. Septic shock in humans. Advances in the understanding of pathogenesis, cardiovascular dysfunction, and therapy. Ann Intern Med 1990;113:227-42. 


\title{
Abstract
}

\section{Fever and antipyretic therapy in critically ill patients}

\author{
Moritoki Egi*1, Masaji Nishimura*2, Kiyoshi Morita*1 \\ ${ }^{* 1}$ Intensive Care Unit, Department of Anesthesiology and Resuscitology, Okayama University Hospital \\ *2 Emergency and Critical Care Medicine, University of Tokushima Graduate School \\ *1 2-5-1 Shikata-cho, Okayama, Okayama 700-8558, Japan \\ *23-18-15 Kuramoto-cho, Tokushima, Tokushima 770-8503, Japan
}

Background: Fever is common in critically ill patients. Antipyretic therapy for fever is routinely performed in intensive care. However, there is not sufficient information on how body temperature should be controlled in non-neurological critically ill patients (ICU patients). Methods: We have conducted a systematic review of the literature to assess the impact of fever and antipyretic therapy on mortality in ICU patients. Results: Our literature search retrieved twenty-seven articles. Review of these articles revealed that 1) fever is associated with increased mortality, 2) among ICU patients with infection, fever may be associated with decreased mortality, 3) there have been no observational studies to assess the relationship between fever and mortality in ICU patients in which information on antipyretic therapy was included, 4) aggressive antipyretic therapy (starting when body temperature is $>38.5$ degrees Celsius) tends to increase mortality. Conclusions: Data on fever and antipyretic therapy in ICU patients are insufficient to guide a choice of therapy. A randomized controlled trial would be ethically difficult to conduct. Large multicenter observational trials are needed to understand the interaction among fever, antipyretic therapy and outcomes in ICU patients.

Key words: (1) fever, (2) antipyretic, (3) mortality, (4) critically ill, (5) systematic review

J Jpn Soc Intensive Care Med 2011;18:25 32 . 